\title{
Macromycetes of oak forests in the Jurassic Landscape Park (Częstochowa Upland) - monitoring studies
}

\author{
MARIA LAWRYNOWICZ. \\ Department of Algology and Mycology, University of Lódz \\ Banacha 12/16 PL-90-237 Lodz, Poland
}

Law tynowicz M: Macromycetes of ank forests in the Jurassic Landscape Park (Czestochowa Upland) - monitoring studies. Acta Mycol. 36 (1): 81-110, 2001.

Mycological observations were carried out between 1994-1996 in two representative plots (1000 $\mathrm{m}^{2}$ each) in 80-year-old oak plantation (Quercus robur and $Q u$. petraea) on calcareous hill in the Mstow village in the Jurassic Landscape Park. The project was carried out in the frame of international network of the „Mycological monitoring in European osk forests". During 24 visits in the plots a votal of 190 species of macromycetes was recorded: 80 mycorthizal and 110 saprobic fungi. Among them 2 species are new to Poland and 16 are inscribed in the Red List of threatened macromycetes in Poland (Wojewoda and Lawrynowicz 1992)

Key words: macromycetes, mycological monitoring, oak decline, Poland.

\section{INTRODUCTION}

The oak belongs to the most important forest trees widely distributed in Europe. However, in the last decades it has showed regionally reduced vitality and local die-back. This phenomenon has been also observed in Poland (Przybyl 1995). Fungi and their communities seem to be very useful bioindicators of the forest deterioration. Following the proposal by Fellner and Arnolds (1991), three countries started to co-operate within the project of „Mycological monitoring in European oak forests" (Perini, Lawrynowicz and Fellner 1995). The project includes studies of fungal communities in various types of oak woods along the north-south transect through Europe - from the Baltic Sea in Poland towards the Czech Republic to the Mediterranean area in Italy (Perini et al. 2000).

In Poland 16 permanent plots in 7 localities in different parts of the country were established in representative stands in the forests of various typc and management, from virgin forest to plantations. The plots were investigated 3 years according to uniform methods used in the project. 
Subsequent detailed reports on the observation series performed in Poland have been already published by $\mathrm{L}$ i s i e w $\mathrm{s} \mathrm{k}$ a and $\mathrm{P}$ o $\mathrm{L} \mathrm{c} \mathrm{z}$ y $\mathrm{s} s \mathrm{k}$ a (1998), S k irgie $110(1998)$, Lu sz c z y ńs ki (1998), W oje wo da, Hein. r i c h and K o mor ow s a (1999), L a w r y n ow i c z and S t a s i n$\mathrm{ska}(2000)$. The present paper will be followed by the work on the observations made in Central Poland by $\_$a w r y n ow ic z, K a l u ck a and $\mathrm{S} u \mathrm{~m}$ or o $\mathrm{k}$ (2001).

I am indebted to the following persons for their help: Prof. E. Parmasto, Prof. W. Wojewoda and Dr L. Krieglsteiner for helping in determination of scme wood-inhabiting fungi, Prof. J. Jakubowska-Gabara for phytosociological elaboration of observation plots, Dr M. Stasińska, Dr 1. Kałucka, Dr M. Ruszkiewicz-Michalska, Dr J. Szkodzik, Dr J. Zelazna-Wieczorek, mgr D. Seta and G. Samek for assistance in field studies and help in preparation of the manuscript for pablication; mer D. Babska for drawing the map.

\section{STUDY AREA}

Two permanent plots, I and II, assigned as P5 and P6 in the project, were selected in the Jurassic Landscape Park in the village Mstow situated ca. $13 \mathrm{~km}$ NE of the Czestochowa town (Fig. 1).

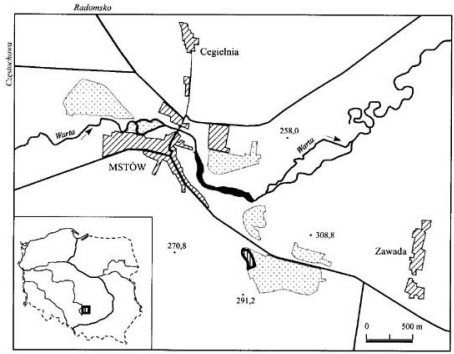

Fig 1. Location of the study area in the Jurassic Landscape Park 
An oak plantation, established in 1920, replaced the old forest burnt during the I World War. It covers a slope of calcareous hill of $250 \mathrm{~m}$ a.s.l at the edge of deciduous forest. The oak plantation is surrounded in WS by an open xerothermic pasture and on the other sides by mixed deciduous forest with stand consisting of Betula pendula, Fagus sylvatica, Quercus robur and Pinus sylvestris. The soil type is determined as rendzina, pH $6.5-7$.

The mean monthly and mean annual temperatures, as well as monthly and annual precipitation totals are given in Tables 1 and 2 , respectively.

After 80 years of afforestations the vegetation changed conspicuously. According to phytosociological analysis made by $\mathbf{J}$ a k u bow s k a - G a b a r a (1996) the plots are covered with the Quercus-Brachypodium pinnatum community.

$T$ a b I e 1

Mean monthly and mean annual sir temperatures for the meteorological station in Czestochowa $\left[{ }^{\circ} \mathrm{C}\right]$

\begin{tabular}{|r|rrrrrrrrrrrrr|r|}
\hline $\begin{array}{r}\text { Ycar/ } \\
\text { Moath }\end{array}$ & I & II & III & IV & V & VI & VL & VIII & IX & X & XI & XII & I-XII \\
\hline 1994 & 2.2 & -1.6 & 4.5 & 8.8 & 12.6 & 16.5 & 22.2 & 18.4 & 14.7 & 6.5 & 3.8 & 1.0 & 9.1 \\
1995 & -1.5 & 2.8 & 2.4 & 7.6 & 12.4 & 16.6 & 20.4 & 18.2 & 12.5 & 10.8 & 0.5 & -4.4 & 8.2 \\
1996 & -5.4 & -5.1 & -1.9 & 7.5 & 14.1 & 16.9 & 16.2 & 17.6 & 9.7 & 9.1 & 5.3 & -5.4 & 6.6 \\
\hline
\end{tabular}

Table 2

Monthly and annual precipitation totals for the meteorologieal station in Częstochowa [mm]

\begin{tabular}{|r|rrrrrrrrrrrr|r|}
\hline $\begin{array}{r}\text { Year/ } \\
\text { Month }\end{array}$ & I & II & III & IV & V & VI & VII & VIII & IX & X & XI & XII & I-XII \\
\hline 1994 & 51.7 & 7.6 & 79.3 & 89.2 & 97.8 & 33.3 & 44.9 & 114.8 & 70.7 & 49.4 & 26.3 & 50.5 & 715.5 \\
1995 & 35.3 & 46.7 & 38.1 & 50.0 & 57.1 & 92.0 & 72.2 & 82.6 & 74.2 & 10.3 & 34.8 & 32.7 & 626.0 \\
1996 & 22.2 & 30.3 & 18.3 & 51.8 & 110.9 & 87.0 & 110.4 & 78.0 & 111.2 & 38.7 & 55.7 & 12.3 & 726.8 \\
\hline
\end{tabular}

\section{METHODS}

Mycosociological survey was made according to standard methods in two permanent plots of $1000 \mathrm{~m}^{2}$ divided into 10 subplots (Fig. 2). The studies were carried out from the summer 1994 to the late autumn 1996. The species diversity of macromycetes, their abundance, frequency, and trophic groups were recorded monthly. Altogether 24 field observations were made. The location of trees, stumps and fallen branches in each plot was charted (Fig. 2). The fungi were analysed regarding the ecological groups - mycorrhizal symbionts and saprotrophs. All fruit-bodies were noted on each squarc, as wcll as all comments concerning the substrate: soil (s), wood (w), litter (l). Single specimens growing on dead grasses and old mushroom fruit-bodies are assigned to litter-inhabiting fungi group. All species are listed in Table 4 and 5 with indication of: SF - spatial frequency; TF - temporal frequency; 
DCy - total number of fruit-bodies in a year, $\mathrm{mDCv}$ - maximal number of fruit-bodics in the plot recorded during one visit.
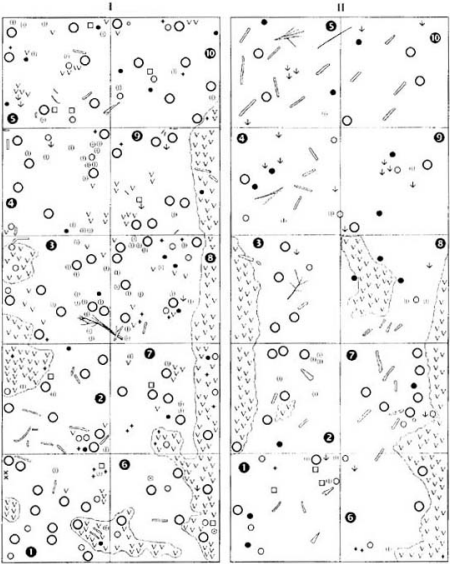

Fig. 2. Structure of the tree stand in the plots

Quercus: 0 - living tress, - - stumps; $\square$ - Sorbus aucuparia; $\oplus$ - Cratacgus monogyna; $V$ - Pronus spinosa; 1 - Juniperus commuris; + - Rosa canina; $\times$ - Euonymus europaeus 
Phytosociological releves were made by professional botanist - Prof. J. Jakubowska-Gabara, who described all 16 monitoring plots involved in the project in Poland using Braun-Blanquet method. The phytosociological results are presented in Table 3. Tables 4 and 5 are prepared in accordance with the previously published results concerning the other plots in Poland. Special attention was paid to the qualitative and quantitative analysis of macromycetes. Differences in fungal composition between the plots, as well as the ratio of mycorrhizal to saprotrophic species are shown in Table 6 and 7 .

The following works were used for the identification of species and as a source of nomenclature: D e n $\mathrm{n}$ is (1968), D o mań s k i (1972), D omański, Orloś and Skirgie Ho (1973), Wojewoda (1977), Moser (1978), J ülich (1984), K r e iscl (1987), Hawksworth et al. (1995). Names of vascular plants are according to $\mathrm{M}$ i r e k et al. (1995).

\section{REMARKS ON THE VEGETATION}

The area is interesting both for mycologists and botanists. It is rich in macrofungi, occurring especially abundantly in forest, and rich in vascular plants, growing on calcareous soil in forest and in open places ( $\mathrm{L}$ a w r y n o w ic z 1986). The phytosociological releves of mycologically investigated plots are presented in Table 3.

In the vicinity of the mycological plots the area of interesting botanical monitoring is situated as well. The observations on the introduction of two species threatened in Poland - Carlina onopordifolia and Inula ensifolia - are carried out here. The plants are in danger of extinction in native localities. The experiment of so called "metaplantation" succeeded - both plants are flowering. The attention of botanists, and local inhabitants as well, is also focused on other rare plants, e.g. Anemone sylvestris, Orchis mascula, Carlina acaulis, Gentiana ciliata and Digitalis grandiflora.

\section{Description of permanent plots}

The plots are close to each other but vary in exposition, density of the undergrowth and intensity of human impact (penetration by people).

Plot $\mathrm{I}$ is a rectangle $20 \mathrm{~m} \times 50 \mathrm{~m}$, situated on NW slope (exp. $30^{\circ}$ ) of calcareous hill, ca. $200 \mathrm{~m}$ a.s.l. The soil is of the rendzina type (pH 7). It is occupied by the Quercus-Brachypodium pinnatum community (Table 3 ). The tree stand consists of 80-year-old oaks - prevailing Quercus robur and $Q u$. petraea. Crowns density reaches $50-70 \%$. The shrub layer consists of Prumus spinosa. Crataegus monogyna, Rosa canina, Sorbus aucuparia and Juniperus communis. The herb layer is dominated by Brachypodium pinnatum $(80-100 \%)$. Oak stumps and fallen branches are present in the plot. Close to its border the specimen of Betula pendula is growing. The plot is crossed by the path used by people to climb the hill. 


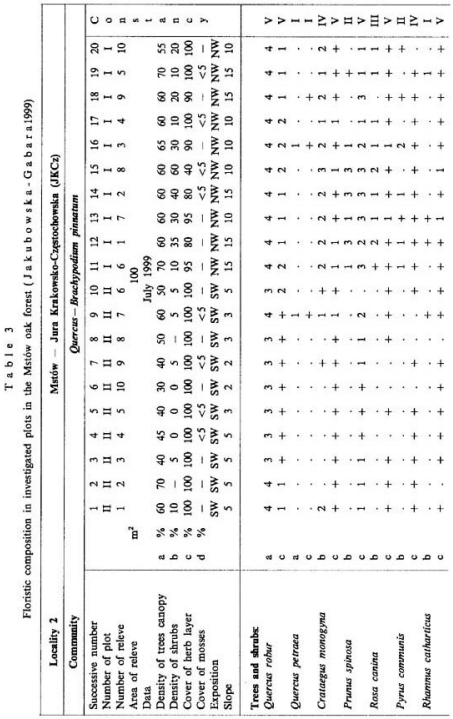




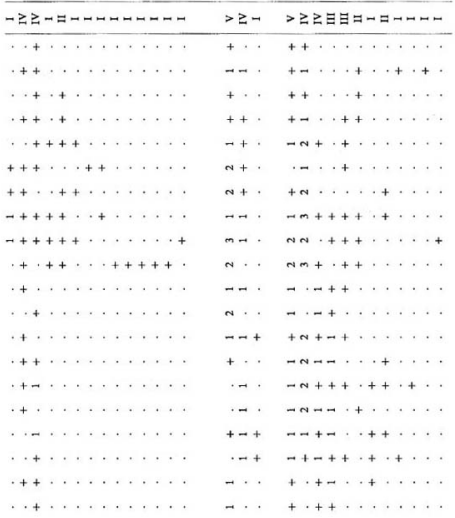

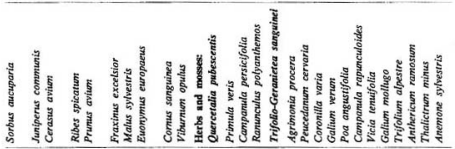



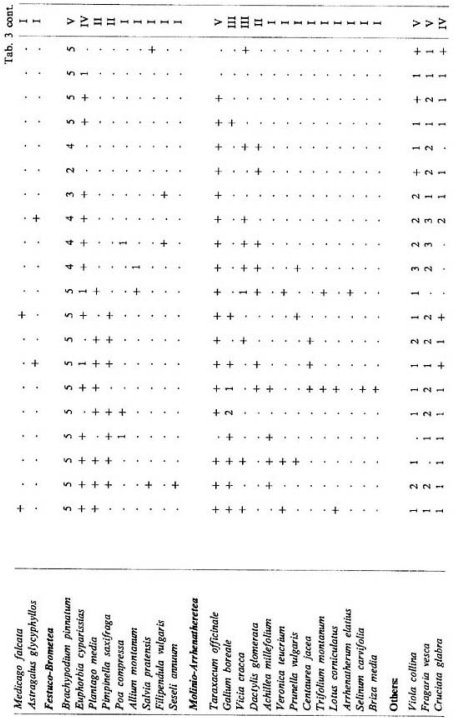


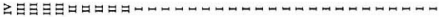
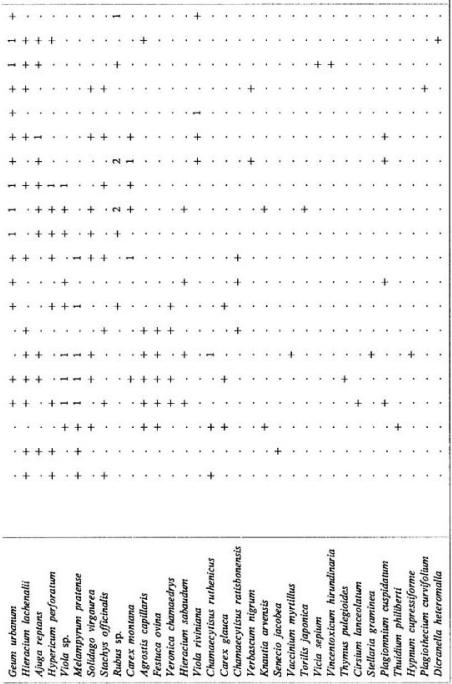
Plot II is of the same dimensions, but is situated on the WS slope of the hill (exp. $10^{\circ}$ ). The soil type, as well as plant community is as above. The soil $\mathrm{pH}$ amounts to 6.5. The tree stand consists of 80-year-old Quercus robur accompanied by $Q u$. petraea, crowns density reaches $50 \%$. The shrub layer is poorly developed, with single Juniperus communis, Rosa canina, Sorbus aucuparia, Crategus monogyna, and some groups of Prunus spinosa, mostly near the border of the plot (Fig. 2). Although the shrub layer varies in different subplots, its average coverage does not exceed $5 \%$. The herb layer is dominated by Brachypodium pinnatum ( $80-100 \%)$. Oak stumps and fallen branches are present in the plot. Because the plot is open on the SW side and the undergrowth is poor, the late autumn winds partly take the leaf litter away, The area is penetrated by people looking for mushroom and by people coming out from the forest to admire a beautiful panorama of Jurassic landscape and xerothermic vegetation.

\section{RESULTS}

No essential differences in the occurrence of fungi and their spocies composition were observed between the plots. It results from a great similarity of habitat conditions: the tree stands consist exclusively of oak in the same age, soil and vegetation cover are also uniform. However, variable density of the undergrowth, different slope exposition and intensity of human impact caused remarkable qualitative and quantitative changes in fungi occurring on the plots.

Plot I. Altogether, 142 species were distinguished. Detailed data concerning abundance of fruit-bodies, their spatial frequency (SF) and temporal frequency (TF) are given in Table 4. According to the numbers of fruit-bodies produced by particular species two opposite groups of species can be distinguished: one with large amount of fruit-bodies and the other with single individuals during the period of three years. There were 22 species which produced more than 100 fruit-bodies, and among them 6 species with abundance above 200, e.g. Mycena vitilis - 492, Laciarius quietus - 415, Cortinarius trivialis - 309, Leotia lubrica - 246, Collybia dryophila - 226, Marasmius rotula - 218. The abundant species were mostly homogeneously distributed in the plot, but some of them were limited to particular subplots, e.g. 195 fruit-bodies of Armillaria mellea were collected only in two subplots and what is more the numbers of fruit-bodies varied from year to year, e.g. 139 in 1994, 56 in the next year and no fruit-bodies in the last year. Amanita phalloides was noted during the first two years, but Coprinus domesticus - during the two last years. 


\begin{tabular}{|c|c|c|c|c|c|c|}
\hline 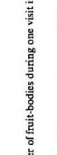 & $\begin{array}{l}\frac{2}{3} \\
\frac{1}{2} \\
\stackrel{2}{2}\end{array}$ & d & & ఫ্ & $=$ & 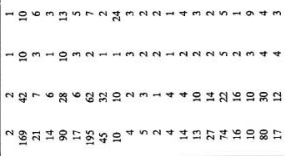 \\
\hline 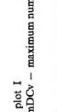 & $\stackrel{\circ}{\vdots}$ & $\sigma$ & से & 仓े & 으 & 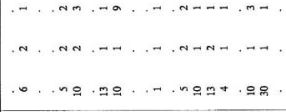 \\
\hline 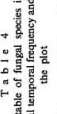 & ळू & $\infty$ & 옹 & ঠ్ర & n & 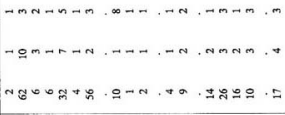 \\
\hline 落台 & 志 & $m$ & $E$ & 岁 & $m$ & 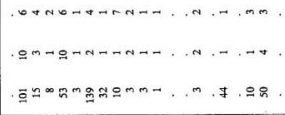 \\
\hline 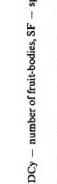 & है & 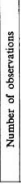 & 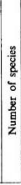 & 웜 & - & 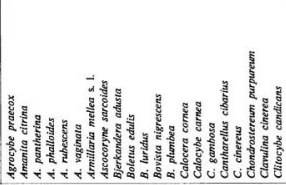 \\
\hline
\end{tabular}




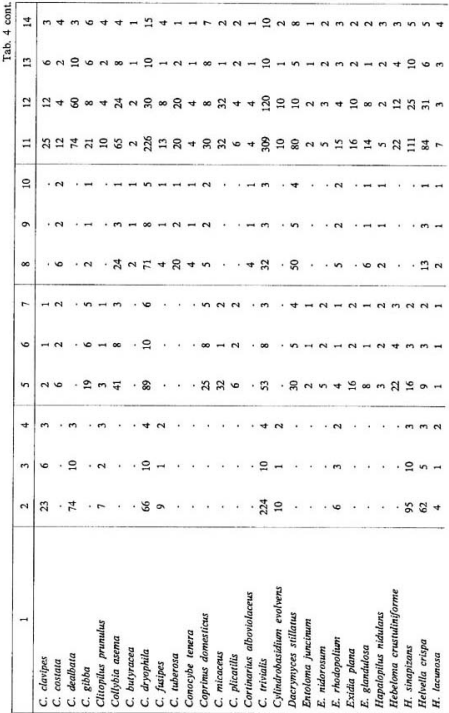




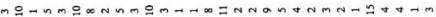

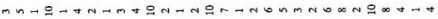
$\infty$ 에

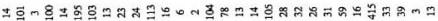

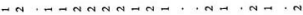
$m$ m. e

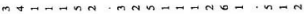

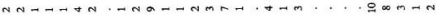

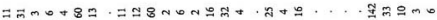

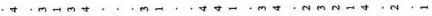

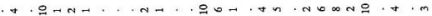
. 


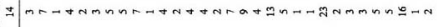

b

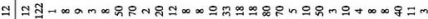

$\exists$ 웍에

\begin{tabular}{|c|c|c|c|c|c|c|c|c|c|c|c|c|c|c|c|c|c|c|c|c|c|c|c|c|c|c|}
\hline 으 & $\cdot N$ & & $\mathrm{CN}$ & ' & $N$ & $r$ & Co & $+\mathrm{N}$ & $\mathrm{N}$ & + & 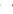 & , & $+\rightarrow$ & $\mathrm{N}$ & $\rightarrow r$ & $N$ & + & $++\infty$ & $\mathrm{N}$ & $\mathrm{N}$ & $\mathrm{N}$ & - & $\cdot m$ & & $\rightarrow$ & + \\
\hline 0 & $\cdot \infty$ & & $\mathrm{CA}$ & ' & $\mathrm{N}$ & 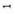 & m & $+\infty$ & $\mathrm{N}$ & • & + & + & $\rightarrow$ & $\infty$ & $n$ 으 & $\infty$ & • & $+\underline{0}$ & $\mathbf{N}$ & $r$ & $\rightarrow$ & , & $+\infty$ & $\infty$ & $\mathrm{C}$ & , \\
\hline 0 & $\cdot \frac{n}{n}$ & & $\infty$ & + & $n$ & $\infty$ & $\cdot \ddot{6}$ & , 용 & $\stackrel{\infty}{\rightarrow}$ & + & + & , & 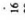 & 요 & $\stackrel{\infty}{=}$ & 8 & + & + + & $\checkmark$ & 으 & 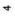 & . & $\cdot+7$ & $7=$ & $\exists$ & . \\
\hline$r$ & $\rightarrow \mathrm{N}$ & $\rightarrow$ & N & $N$ & - & 8 & $m \backsim$ & $\Rightarrow-$ & . & $\nabla$ & - & & $N m$ & n & $m m$ & $n m$ & • & $\Rightarrow \infty$ & + & $m$ & $\Rightarrow$ & $m$ & $\mathrm{~N}$ & 우 & . & . \\
\hline 6 & $-N$ & $\Rightarrow$ & $m$ & $m$ & - & $m$ & $m m$ & $\mathrm{NN}$ & , & $\mathrm{N}$ & $\mathrm{N}$ & & $\mathrm{N} m$ & $a$ & $\omega$ 으 & 20 & • & $+r$ 음 & + & -1 & -1 & 4 & $m e$ & $N$ & + & . \\
\hline n & $\mathrm{N}=$ & - & 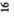 & $=$ & $m$ & $a$ & 우 & * สิ & . & $\underline{\theta}$ & $\infty$ & & $\infty=$ & 2 & సొ స్త్ & 웍 & . & -으욤 & . & 으 & $\mathrm{N}$ & 9 & & 웅 & - & . \\
\hline 8 & $m m$ & - & - & , & • & * & $\mathrm{NO}$ & $+\rightarrow$ & , & * & $m$ & & $m$ & $N$ & - $m$ & , & -5 & , & $\cdot$ & • & • & $\mathrm{N}$ & $\mathrm{me}$ & $m$ & & $N$ \\
\hline$m$ & b m & - & - & $\therefore$ & - & * & $\mathrm{Nm}$ & $+\Rightarrow$ & , & • & - $\mathrm{N}$ & & $m$ & $\nabla$ & -용 & , & - & , 음 & + & $\cdot$ & + & $N$ & $m e$ & & & $\rightarrow$ \\
\hline & $8 n$ & - & * & ' & - & - & 성요 & .으 & . & - & 9 & & .6 & 으 & - 㝵 & 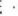 & in & , 垂 & , & , & , & 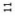 & $\Rightarrow$ & 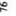 & & $m$ \\
\hline
\end{tabular}

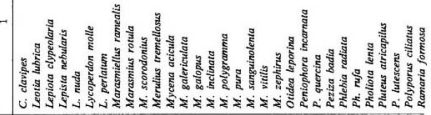




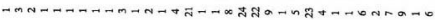

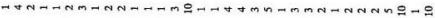

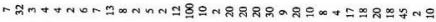

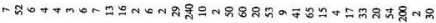

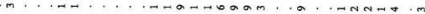

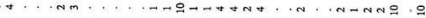

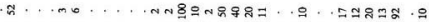

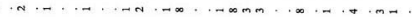

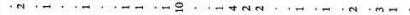

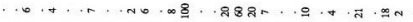

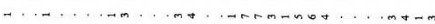

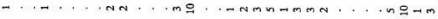

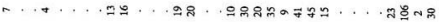

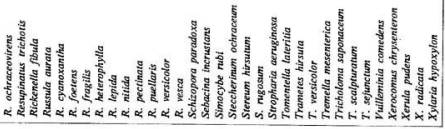


The second group consists of macromycetes producing a small number of fruit-bodies. Altogether 38 species with number of carpophores below 10 were recorded; they were usually limited to one or two subplots.

Frequency of carpophores (TF during 24 visits and SF in 10 subplots) was also variable:

- 33 species were collected only once

- 37 species - only in one subplot

- 23 species only once in one subplot (the remaining 10 - in 2 subplots). On the other hand:

- 17 species were collected at least 10 times

- 17 species in all subplots

- 9 species were noted at least 10 times in all 10 subplots.

The number of species noted only once varied in years: $1994-7 ; 1995$ $-15 ; 1996-11$.

Trophic groups are indicated in Tables 6 and 7. There were 58 mycorrhizal species in plot I; 12 species were found exclusively in this plot, c.g. Hysterangium coriaceum, rare hypogeous fungus. The presence of two other species: Lactarius necator and Russula nitida is connocted with the presence of Betula in the vicinity of the plot.

The group of saprotrophic fungi consisted of 84 species (18 collected exclusively in plot I); among them 23 were growing on soil, 46 on wood and 15 on the litter layer.

Plot II. In total, 159 species of macromycetes were collected. The number of specics which produced more than 100 fruit-bodies amounted only to 19 ; among them there were only two species with the total abundance of carpophores over 200: Mycena vitilis - 245 and Xerula pudens - 227. Other species worth noticing are: Leotia lubrica - 194, Collybia asema - 186, Amanita citrina - 174, Lactarius quietus - 164, Marasmius rotula - 192 carpophores. Some of the abundantly fructificating species were limited to single subplots, Armillaria mellea with 172 specimens in two subplots only and C. cinereus with 40 fruit-bodies also in two subplots and what is more collected only once. 


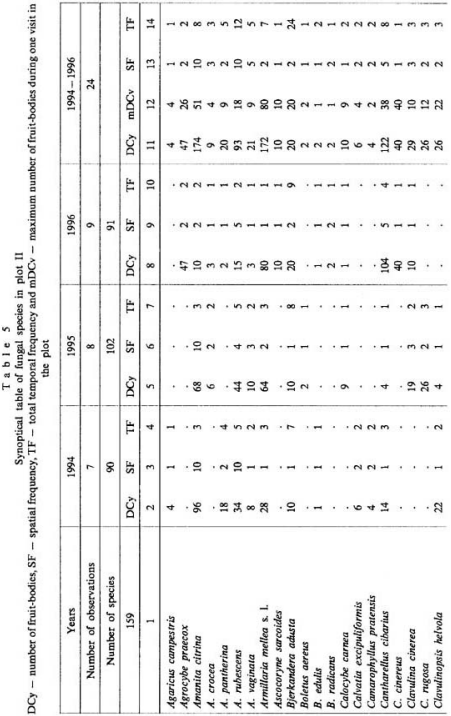




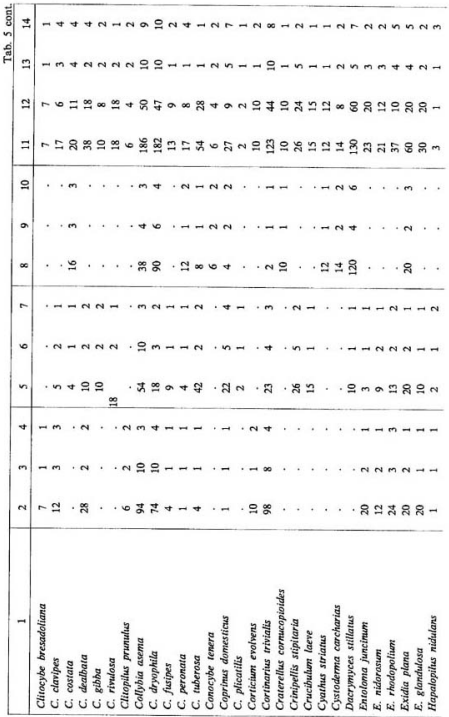




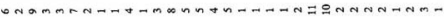

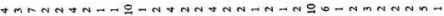
욤요 ลํํำ m co n.

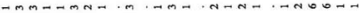
$m$ m유

$\mathrm{CA} \rightarrow \mathrm{CAC}=\mathrm{C}$ $\rightarrow N m$

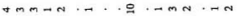
$-\infty m$ a n in $\vec{n}$ 잉

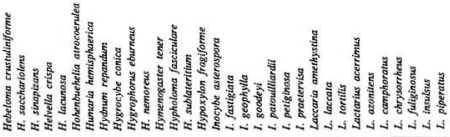




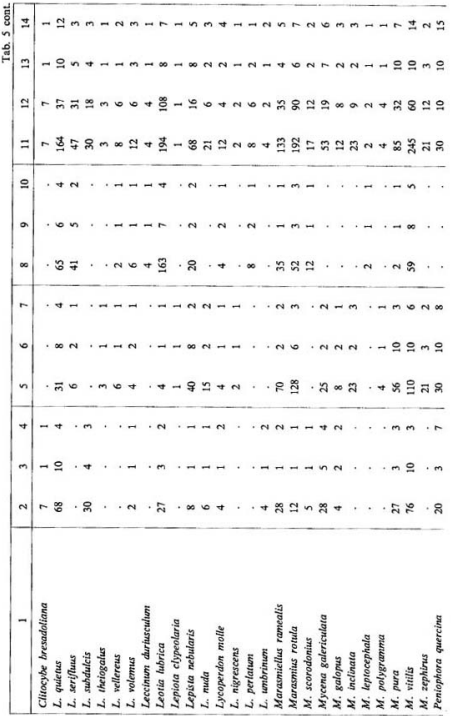




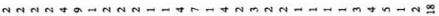

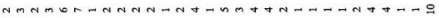

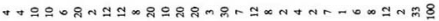

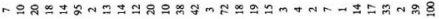
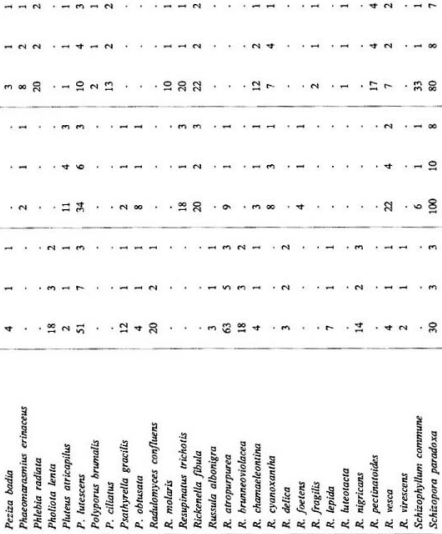


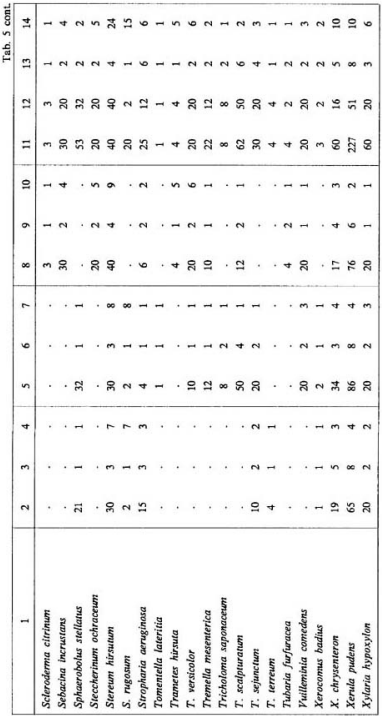


The second conspicuous group of fungi consists of species which produced a small amount of fruit-bodies. 47 species were represented by single specimens (the number of carpophores not exceeding 10) collected during the three years and limited usually to one or two subplots.

The frequency of carpophores (TF during 24 visits and SF in 10 subplots) was also variable:

- 41 species were collected only once

- 44 species - only in onc subplot

- 31 species only once in one subplot.

On the other hand:

- 12 species were observed at least 10 times

- 12 species in all subplots

- 7 species noted at least 10 times in all subplots.

The number of species noted only once varied in years: $1994-7 ; 1995$ - 15; 1996 - 17.

To sum up, in plot I and II, 142 and 159 fungal species were found, respectively: 30 species were collected only in plot I and 46 only in plot II.

\section{Trophic groups}

The mycorrhizal and saprotrophic specics are indicated in Tables 6 and 7, respectively. No real parasites were found in the macromycete group.

Among the species collected, as many as $80(41 \%)$ were mycorrhizal: 58 in plot $I$ and 68 in plot II. The specimens seem to be associated with oaks: Quercus robur and Qu. petraea equally. The plots had 46 species in common, 12 were found only in plot I and 22 only in plot II.

The group of saprotrophic fungi consisted of 110 species: 84 in plot $I$ and 91 in plot II. The plots had 68 species in common, 18 were collected only in plot $I$ and 24 only in plot II. The group comprised 56 species inhabiting wood, 31 species growing on soil and 22 -on litter. 
T a b 1 e 6

List of mycorrhizal species collected during the three year research (1994-1996) in two permanent plots

\begin{tabular}{|c|c|c|c|}
\hline Species & $\begin{array}{c}\text { Number } \\
\text { of fruit- } \\
\text { bodies }\end{array}$ & Species & $\begin{array}{l}\text { Numbet } \\
\text { of fruit } \\
\text { bodies }\end{array}$ \\
\hline \multicolumn{4}{|c|}{ In plots I and II } \\
\hline Lacterites quilenes (Fr) Fr. & 579 & Amanîta pantherina (DC: $\mathrm{Fr}$ ) Krombh. & 41 \\
\hline Cortinarius urivials Lge. & 432 & Lactarius chrysartheted $\mathrm{Fr}_{\mathrm{f}}$ & 41 \\
\hline Amonita ettrine (Schaeff) Pers & 343 & Amanita soginata (Bull.Fr.) Vitt. & 38 \\
\hline Ifyropharut elumes (Bull.: Fr.) Fr. & 270 & Laciarius fullghoris $\mathbf{F L}$ & 36 \\
\hline Lacearia emethyrtina (Huds, ex Hook.) Cke. & 264 & Lacierilus camphoraties (Bull.) $\mathbf{F}_{\text {f. }}$ & 36 \\
\hline Hebeloma singoizrms (Pavit: Fr.) Gill. & 263 & Laccarta tarifir (Bolt) Cie. & 34 \\
\hline Amanita nubercens Pres, (; Fr.) & 183 & Hymenagasier tener Berk. st Br. & 27 \\
\hline Cantherelitur efbaries $\mathrm{Fr}$. & 196 & Entoloma nidorarem (Fr.) Qutl. & 26 \\
\hline Laccaria lacceta (Scop: $\mathbf{F}_{\mathrm{r}}$ ) Bk, et BK. s. 1. & 145 & $\begin{array}{l}\text { Entoloma juncinum (Kuehn, et Romagn) } \\
\text { Noord. }\end{array}$ & 25 \\
\hline Inocybe geephyla (Sow: Fr) Kuram. & 125 & Lacuarìus volentur $\left(F_{\mathrm{f}}\right) \mathrm{Fr}_{\mathrm{r}}$ & 25 \\
\hline Lastarias acerrimus Britz. & 120 & Lactarius azonates (Bull) $\mathrm{Fr}$. & 20 \\
\hline Xerocamus chrysenteren (Bull) Quel. & 114 & Ruenta lopiea $\mathrm{Fr}$. & 20 \\
\hline Hebeloma crustuliniforme (Bull) Quel. & 81 & lnocybe goodeyt GLL. & 18 \\
\hline Latiofitus serifline (DC: $\left.\mathrm{Fr}_{-}\right) \mathbf{F t}$. & 80 & Clitopilas prusulus (Ssop: Fr.) Kumm. & 16 \\
\hline Tricholama scalphuratum (Fr.) Quél. & 79 & Ruerdia cyanoxanthe (Schaeff) $\mathbf{F t}$. & 19 \\
\hline Lactarius sabdukis Bull: Fr. & 69 & Inocybe sraetervisa Quél. & 13 \\
\hline Tricholama sejunctum (Sow: Fr) Quel. & 63 & Trichoiome soponasetum (Fr) Kumm. & 12 \\
\hline Resrala nesce $\mathrm{Fi}_{\mathrm{i}}$. & 62 & Lactarks velleress (Fr) Fr. & 11 \\
\hline Cantharelhut dinereus Pers: Fr. & 56 & Inocybe petiginosa (Fr) Gill. & 10 \\
\hline Inocybe fastigfina (Schaefi.) Qutl. & 53 & Hydnum repandum $\mathrm{L}$. & 8 \\
\hline Entolama phodopolitom (Fr: $\mathbf{F r}$ ) Kumm. & 52 & Rustula fragitis $(\mathbf{F r}$ ) $\mathbf{F r}$. & 8 \\
\hline Lacherius onnutear $\mathrm{Fr}$. & 52 & Ruesula foetent $\mathrm{Fr}$. & 7 \\
\hline Inocybe atterouspora Qutl. & 48 & Boietus edulis Bull: Fr. & 6 \\
\hline \multicolumn{4}{|c|}{ Ody ia plot I } \\
\hline Lactarius mitticrimus $\mathrm{Fr}$. & 59 & Rusnda puellaris $\mathrm{Fr}$. & 6 \\
\hline Lactarius necator (Bull. En Pers: Fr) Karxt & 16 & Boletes horidw Schaelf: Ft. & 5 \\
\hline Ruscrda nutida ( $\mathrm{Pcrs}$ : Fr) $\mathrm{Fr}_{\mathrm{r}}$ & 16 & Contharius albowiolacews (Pers: Fr.) Pouz. & 4 \\
\hline Amonite phatloides (Fr.) Link & 14 & Rutru'c ourale (With) Fr. & 4 \\
\hline Hyrterangiam corisonem Hesse & 13 & Rustida pectinate $\mathbf{F}$. & 2 \\
\hline Ricenda heterophylla (Fr.) Fr. & 7 & Ruernila versicoler Schaeff. & 2 \\
\hline \multicolumn{4}{|c|}{ Only in plot II } \\
\hline Ruevda etropurpured (Krombl.) Britz. & 72 & Camarophylhus pratensis (Fers: $\mathrm{Fr}_{\mathrm{s}}$ ) Kunas & 4 \\
\hline Hebeiome sancheriolens Quet. & 22 & Tricholame terreum (Sehs. Fr.) Kumm. & 4 \\
\hline Rucruda chamaeleontia (Fr) Fr. & 19 & Xerocamus badiut (Fr.) Kuehn. Gitb. & 3 \\
\hline Rusnda brunneoviolacea Crawsh. & 18 & Lectariur theiogalus (Bull: Fr) S.F.Gray & 3 \\
\hline Ruerda pectinatoides Pock & 17 & Rucosia albonigra Krbb. & 3 \\
\hline Rusrula nigricans (Bull.) Fr. & 14 & Rusurita delica Fr. & 3 \\
\hline Amanila crocea (Quel.) Sing. & 11 & Beletus radieant Pers: Ft. & 2 \\
\hline Creterellus cornucopioides (L) Pers. & 10 & Rolens arereas Bull.: Fr. & 2 \\
\hline Inocybe patoulliardil Bres. & 6 & Russia virersenst (Schaefl, ex Zeot) Ft. & 2 \\
\hline $\begin{array}{l}\text { Leedinum durtusculum (Kalchbr. \& Schul. } \\
\text { ap. Fr.) Sing. }\end{array}$ & 4 & Lactartus piperater (L.: Fr) Pers. & 1 \\
\hline Hygrophane nemoreut (Pers: Fr.) Ft. & 4 & Rucrula luseotacta Rea & 1 \\
\hline
\end{tabular}


T a b 1 o 7

List of suprotrophic species collected during the three year research $(1994-1996)$ in two permanant plots

\begin{tabular}{|c|c|c|c|c|c|}
\hline Species & 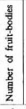 & 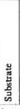 & Species & 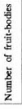 & $\begin{array}{l}\frac{y}{3} \\
\frac{3}{3} \\
\text { कै }\end{array}$ \\
\hline \multicolumn{6}{|c|}{ In ploss 1 aod II } \\
\hline 1 & 2 & 3 & 1 & 2 & 3 \\
\hline Mycena tifüis (Fr) Qué. & 737 & $w$ & 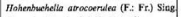 & 47 & w \\
\hline Lectic liabrica Pers. & 440 & $\mathbf{s}$ & Trametes hirsula (Wulf: Ft.) Pil. & 45 & $w$ \\
\hline Schizopera paradoxa (Schrad: Fr.) & 220 & $w$ & Artacenyine sureaides (Jacq: Fr) Groves & & \\
\hline Donk & & & et Wilson & 35 & w \\
\hline Xenula puders (Pers) Siag. & 427 & $w$ & $\begin{array}{l}\text { Exidia gkandilosa (Bull.); } \mathbf{F r},-E \text {. unea- } \\
\text { te } \mathbf{F r} \text {. }\end{array}$ & 44 & $w$ \\
\hline Manasmitus raula (Scop: $\mathbf{F r}$.) Fr. & 410 & $w$ & Cluacybe clavipes (Pers.: Fr.) Kumm. & 42 & 1 \\
\hline Collybia drsoshila (Bull: $\mathbf{F r}_{\text {.) }}$ Kumm. & 408 & 1 & Mycena inclinata (Fr.) Quel. & 41 & w \\
\hline Armillaria mellea (Vahl: Fr) Kumm. s.L & 367 & $w$ & Photiote lenia (Pers: Fr) Sing. & 41 & 1 \\
\hline Hypholame faseiculare (Huds: Fr.) Kumm. & 305 & $w$ & Stereum neasum Pers.: Fr. & 40 & w \\
\hline Vorasmielis rancelis (Bull: Fr.) Sing & 295 & $w$ & Vuilleminia comedens (Nees.: Fr.) R. Maire & 40 & $w$ \\
\hline Piutens romelhi (Britz) Sall & 260 & $\omega$ & Tremella mesenterica Retz: $\mathbf{F r}$. & 37 & N \\
\hline Collybia asema ( $\mathrm{Fr}: \mathrm{Fr})$ Kumm & 291 & 1 & Lepista avda (Bull: Fr) Cooke & 33 & 1 \\
\hline Mycend sephine (Fr: $F_{r}$ ) Kumn. & 259 & 1 & Clitocybe costata Kuehn et Romaga. & 32 & 1 \\
\hline Datyntyecs stililand Nees: $\mathrm{Fr}$ & 201 & 1 & Mycema gatopus (Pers: Fe) Kumm. & 32 & $s$ \\
\hline Pentophitore quercina (Pers: Fr.) Coole & 180 & w & Sebacina incrutans (Pers: $\mathbf{F r}$.) Tul & 32 & $w$ \\
\hline Schirophyllum comimuere $F_{r i} \mathbf{F}_{t}$ & 180 & w & Clitacybe gibbe (Pert: Fr.) Kumm. & 31 & 1 \\
\hline Wyeena pura (Pres: $\mathrm{Fr}_{\text {f. }}$ ) Kumm. & 159 & u & Bjenkandere aduete (Wild: Fr) Karst. & 30 & $w$ \\
\hline Hyphairma nublateriraem (Fr) Quet. & 130 & $s$ & Fhlebta rodiate $\mathbf{F r}$. & 30 & $w$ \\
\hline 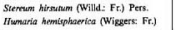 & 100 & n & Pliwient atricaptlllus (Batsch.) Fay. & 30 & w \\
\hline Fuckel & 130 & n & Colblia fisipes (Bull: Fr.) Quel. & 26 & w \\
\hline Clavulina sherea (Bull: Fr) Schrost. & 119 & $s$ & Lycoperidon perlatum Pers: Pers. & 25 & $s$ \\
\hline Mycena polygranima (Bull: Fr.) S.F. Gray & 109 & a & Polypons ciliatus $\mathbf{F r}$ : Fr. & 24 & w \\
\hline Clitocybe delbata (Sow: Fr) Kumm. & 112 & $w$ & Lymperdion mole Pers: Pers. & 20 & $s$ \\
\hline Lepisic nebular's (Batseh: Fr.) Harmaja & 100 & 1 & Calocybe carnec (Bull: Fr) Deak & 15 & s \\
\hline Melnella crispa (Seop.) Fr. & 92 & 1 & Coliybia tuberose (Bull: Fra) Kumm. & 74 & 1 \\
\hline Resupinatus trichotis (Pers) Sing. & 90 & 8 & Mareontius scomadonius (Fr: $\mathrm{Fr}$ ) Fr. & 21 & w \\
\hline Xylaria hypoxvian (L ex Hook.) Greville & 90 & w & 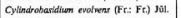 & 20 & w \\
\hline Trameler versicolor (L) PiL. & 90 & w & Helvella lacienasa Afz: $\mathrm{Fr}$. & 18 & s \\
\hline Strapharia aenuginasa (Curtis: Frs) Quel. & 85 & $w$ & Selemaderma eitrinum Pers. & 13 & s \\
\hline Mycena gaiericularg (Scop: Fr) Qub. & 78 & s & Peztza badia Pers. & 11 & $s$ \\
\hline $\begin{array}{l}\text { Sicocherinum achracesen (Pers: Ff.) S.F. } \\
\text { Gray }\end{array}$ & 72 & $w$ & Tomentella laterite Pat. & 10 & $w$ \\
\hline Exidia pians (Wigs.) Donk & 76 & w & Conocybe senera (Schaeff: Fr.) Fay. & 10 & $s$ \\
\hline Coprinur domesticue (Boli: Fr) S.F. Gray & 58 & w & Coprims plicatilis (Cur: $\mathrm{Fr}$ ) $\mathbf{F r}$. & 8 & 3 \\
\hline Agrocybe preecax (Pets: Fes) Fay. & 57 & 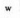 & Hapalopilies nidulans (Pers: Fr.) Karst. & 8 & w \\
\hline Rickenella fibuia (Bull: Fr) Rail h. & 49 & $s$ & Leptoia siypeolaria (Butl: Fr) Kumm. & 2 & $s$ \\
\hline
\end{tabular}


Tab. 7 cont.

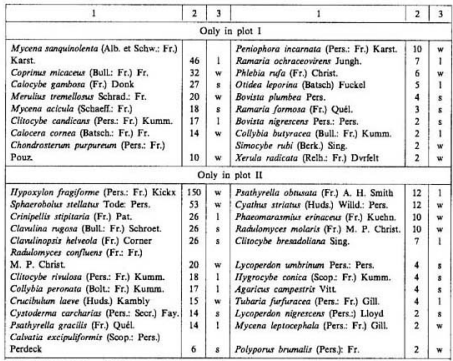

Eological groups: 1 - litrer, $v$ - wond; 8 - sol.

\section{DISCUSION AND CONCLUSIONS}

During the three year study in permanent plots 190 species of macrofungi were found. Among them, 80 were mycorrhizal and 110 were saprotrophic species. No real macromycete parasites were noted. Some species known as parasites, c.g. Collybia fusipes, Armillaria mellea and Schizophyllum commune inhabited only dead stumps of single cut oaks. The stand is relatively young and consists exclusively of oak. This could be considered a factor limiting the number of macromycetes both mycorrhizal and saprotrophic species.

On the other hand, examination of pure oak stand could revealed how many macromycetes were able to form relationships with Quercus robur and Qu. petraea. No difference was noted regarding the affinity between mushrooms and particular oak species. It confirmed the observations made in the Ińsko Landscape Park where Quercus robur and Qu. petraea grew on two different plots ( $\mathrm{taw}$ a n o w i c z and S a s in s k a 2000).

A distinct feature of the forest investigated is its artificial origin as a monocultural plantation, but the number of macromycete species in the plots is comparable with those stated in the other localities searched within the 
project by S k i r g i e 11 o (1998), L is i e w s k a, P o l c z y ńs k a (1998), Ł u s z c z y ńs k i (1998), W o je w o d a et al. (1999) and Ła w r y ow i c z and S t a s i n s k a (2000). Yet, the number of mycorrhiza forming specics collected in the oak plantation is significantly higher $(42,1 \%)$ than in the forest of natural origin including the Białowicza National Park $(21 \%)$ ( $\mathrm{S} \mathrm{k}$ i r g i e 11 o 1998). The lowest ratio (12\%) of mycorrhizal fungi was noted in the Niepolomicka Forest, probably due to the influence of air pollution (W o je w od a et al. 1999).

The group of saprotrophic fungi is quite rich in spite of relative uniformity of the kind and form of substrate, especially wood - there are no logs or other remains of aged trees in the plots, all dick branches are collected periodically by local inhabitants. It could be considered a limiting factor. Total number of 110 saprotrophs is comparable with that found in the other oak forests investigated by the above mentioned authors. Among saprotrophic macrofungi, the largest group of 56 species inhabited oak wood rcmains, mostly small twigs and stumps. These fungi were distributed more or less homogeneously throughout the plots, except for the species growing on stumps, which were limited to the particular subplots.

On the basis of the abundance and frequency of fungi dominant species can be distinguished: Mycena vitilis, Lactarius quietus, Cortinarius trivialis, Peniophora quercina, Schizopora paradoxa, Collybia dryophila, C. asema, Laccaria amethystina, Amanita citrina, A. rubescens. Some abundantly fructificating species were limited to the single subplots, e.g. Armillaria mellea, Bjerkandera adusta, Stereum rugosum, $S$. hirsutum, Hypholoma sublateritium, H. fasciculare or were noted at long intervals e.g. Agrocybe praecox, Hygrophorus eburneus, Cantharellus cinereus, Leotia lubrica, Mararmiellus ramealis.

Relativcly high diversity of fungal species in the plots in pure oak forest is also a result of calcareous soil with $\mathrm{pH} 6,5-7$, hilly configuration of the area and various expositions of the slopes. Several rare species including those inscribed in different categories of threat on the Red List in Poland occur here: $\mathrm{E}$ - Boletus radicans, V - Boletus edulis and Xerula pudens; $\mathbf{R}-$ Lactarius icerrimus, $L$. chrysorrheus, Inocybe goodeyi, Ramaria formosa, Clavulina rugasa and Phaeomarasmius erinaceus; I - Caniharellus cibarius, Tricholoma sejunctum, Lactarius insulsus, Entoloma juncinum, Clitocybe candicans, Otidea leporina and Camarophyllus pratensis. Some of the above species, e.g. Tricholoma sejunctum under oak trees and Phaeomarasmius erinaceus on oak twigs were occurring abundantly and frequently, similarly Xerula pudens, Resupinatus trichotis and Hohenbuehelia atrocoerulea. Two hypogeous basidiomycetes were also found in the plots: Hymenogaster tener in both plots and Hysterangium coriaceum in plot 1 (Tables 4 and 7). 


\section{SUMMARY}

1. In the years 1994-1996 a monitoring study on macromycetes was carried out in a 80-year-old oak plantation on calcareous soil at the Mstów village in the Jurassic Landscape Park.

2. Two permanent study plots were set up in the patches of QuercusBrachypodium pinnatum plant community. Each plot of $1000 \mathrm{~m}^{2}$ was divided into $10(10 \mathrm{~m} \times 10 \mathrm{~m})$ subplots: 24 observations were performed in each of them.

3. During the 3-year studies 190 species of macromyectes were identified: 9 Asco- and 181 Basidionycota. The number of fruit-bodies, as well as spatial and temporal frequency are given for each species.

4. Sixteen species indicated on the Red List of threatened macromycetes in Poland were found. One species, Tomentella lateritia is new to Poland.

5. Some species of fungi abundantly occurring in permanent plots are rare in the country, e.g. Xerula pudens, Tricholoma sejunctum. Phaeomarasmius erinaceus, Boletus radicans, Hohenbuehelia atrocoerulea and Resupinatus trichotis.

6. Among the species collected, 80 are mycorrhizal and 110 are saprotrophic species.

7. Examining the tree stand consisting exclusively of oak enabled observations of the variety and estimation of the number of fungal species associated with this tree. Neither qualitative nor quantitative differences regarding the affinity between macromycetes and particular species of oak: Quercus robur or $Q u$. petraea, were found.

8. Distinct correlation between the increase in fruit-bodies production (frequency and abundance) and the increase in rainfall accompanied by a suitable air temperature (Table 2, 3 and 4,5) was confirmed.

9. On the basis of abundance and frequency a group of dominant macromycetes was distinguished.

10. The numbers of species collected in the two plots investigated are comparable with the numbers of fungi found in the other Polish plots examined in the project.

11. Relatively great number of mycorrhizal fungi ( $42 \%$ of collected species) indicates an active role of mushrooms in the development of oak plantation.

12. It scems that direct and indirect human impact does not injure mycorrhizal association of oak, as evidenced by the abundance of mycorrhizal fungi. That gives a good prognosis for the future of oaks in the area.

The field studies were financed by European Union (contract CIPA CT930/86) 


\section{REFERENCES}

D e n a is R. W. G. 1968 . Beitish Ascamyeeles. J. Cramer, Lehne.

D o m a in s i S. 1972. Fungi. Polyporacece I (resupinatae) Mucronoporaceae I (resupinatae).

For. Sci. Publ. Departm. Nat, Cent, Sci. Techn. Econ. Inform. Warsaw.

D o matiski S, Orlos H., Skirgiello A. 1973. Fungi. Polyporaceae II (pileatae), Mucranoparaceae II (pileatae), Ganndermatacese, Bondarzewiaceae, Baletopsidaceae, Fistulinaceae. For. Sci. Publ. Departm. Nat. Ceat. Sci. Techn. Econ. Iniorm. Warsaw.

Fellner R., A r n olds E. 1991. Proposal for monitoring of macromycetes in European spruce (Picea) and aak (Quercus) forests. In: E. A r n o I d s, H. K r e i s e l (eds). Conser. vation of fungi in Europe. Proceedings of the second meeting of the ECCF, 13-18 Scpt, at Viln. Greifswald: $85-86$.

H a w k w orth D.L., Kirk P.M, S atton B.C, Pegler D.N. 1995. Ainswarth and Bisby's Dictionary of the fungi. $8 \mathrm{ed}$. JMJ Univ. Press, Cambridge.

$\mathrm{J}$ a k u b ow s k a - G a b a $\mathrm{r}$ a J. 1995. Phytosociological documentation of permanent plots in Poland. In: R. F e I I n e r, M. Ł a w r y o w i c z, C. P e r i n i. Mycological monitoring in European oak foresis - the pilot project (msc).

$\mathrm{J} \mathrm{a} \mathrm{k} \mathrm{u} \mathrm{b} \mathrm{o} \mathrm{ws} \mathrm{k} \mathrm{a} \mathrm{-} \mathrm{G} \mathrm{a} \mathrm{b} \mathrm{a} \mathrm{r} \mathrm{a} \mathrm{J.} \mathrm{1999.} \mathrm{Revised} \mathrm{phytosociological} \mathrm{documeatation} \mathrm{of} \mathrm{permanent}$ plots in oak forest in Mstów (msc).

J i $1 \mathrm{i} \mathrm{c} \mathrm{h} \mathrm{W.} \mathrm{1984.} \mathrm{Die} \mathrm{Nichtbldtterpilze,} \mathrm{Gallertpilze} \mathrm{und} \mathrm{Bauchpilze} \mathrm{(Aphyllophorales,} \mathrm{Hetero-}$ basidiantycetes, Gastromycetes), In: H. G a m s (ed,) Kleine Kryptogamenflora 2b/1. Basidiomyceten 1. VEB G. Fischer, Jena.

K re ise I H. (ed.). 1987. Pilzflora der Deutschen Democratischen Republik. Basidianycetes (Gallert-, Hut- und Bauchpilze). VEB G. Fiseber, Jena.

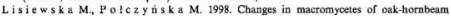
forest in the "Dębina reserve" (Northern Wielkopolska). Acta Mycol. 33(2). 191-230.

La w r y n o w i z M. 1986. Inwentaryzacja przyrodaicza Jurajskiego Parku Krajobrazowego woj. czestochowskim (msc).

Law r y n o w c z M., Stas i i s k a M. 2000 . Macromycetes of the Stellario-Carpinetum in the litsko Landscape Park (NW Poland) - monitoring studies. Acta Mycol. 35(2): 157-182.

$\mathrm{L}$ a w ry now icz M, K a u c ka L, S a mor o K B. 2001. Macromycetes of oak forests in Las Lagiewnicki (Central Poland) - monitoring Studies. Acta Mycol. 36(2).

L u s z o z y n s k i J. 1998. Mactomycetes of the Potentillo albae-Quercetum in the Swietokrzyskie Mts. - monitoring studies. Acts Mycol. 33(2): 231-245.

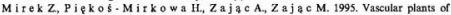
Poland - a checklist W. Szsfer Institute of Botany, Pol. Acad. Sei. Kraków.

M os e r M. 1983. Die Röhrlinge und Blätterpilze (Polyporales, Boletales, Agaricales, Ruzcsulales). In: H. G a m s (ed.) Kleine Kryptogamenflora 2b/2. Basidicmyceten. 2. VEB G. Fischer, Jena.

P e tin i C., La w ₹ y a ow i c z M., F e / I n e t R. 1995. Mycological monitoring in European oak forests: the pilot project for Italy, Poland and Czech Republik. XII Congress of Eutopean Mycologists, 3-7 September, Wageningen, The Nethetlands: 47-48.

Perini C, Saleriai E, Lagana A, Barluzzi, V. De Domiaicis, Lawr $y$ n ow i c z M., F e 11 n e r R. 2000. Monitoraggio de macromiceti in querceti europei: primi resultati di un progetto pilota. Micologia 2000: 415-421. A.M.B. Fondazione Centro Studi Micologici.

P r z y b y \& K. 1995. Zamieranie dębów w Polsce. Idee ekologicze 8(4). Instytut Dendrologii PAN. Sorus, Poznań-Kómik, $85 \mathrm{pp}$.

S k i rgi c t t o A. 1998. Macromycetes of oak-hombeam forests in Bialowieza National Park - monitoring studies. Acta Mycol. 33(2): 171-189.

W ojewo da W. 1977. Flor2 Polska. Grzyby (Mycola), 7: Auricularilaes, Septabasidiales, Trenzellales. PWN, Warszawa-Kraków.

Woje wo da W, L a w $r$ y n ow i z M. 1992. Rod list of threatened macrofungi in Polend.

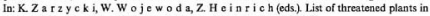
Poland. zed. W. Szafer Institute of Botany PAN, Kraków: 27-56. 
Wojewoda W, Heinrich Z, Komorowska H. 1999. Macromycetes of oaklime-hornbean woods in the Niepolomice Forest near Kraków (S Poland) - monitoring studies. Acta Mycol. 34(2): 201-266.

\section{Macromycetes lasu dębowego w Jurajskim Parku Krajobrazowym} (Wyżna Czçstochowska) - studia monitoringowe

\section{Streszczenie}

Praca przedstawie wyniki badan grzybów makroskopowych w latach 1994-1996 na dwóch stałych powierzchaiach obserwacyjnych zalozonych w lesie komunalnym w Mstowie na tecenie Jurajskiego Parku Krajobrazowego w ramach miętzynarodowego projektu badawczego , Mycological monitoring in European oak forests". Celem projektu, sterowanego przez Unie Europkjsk4 była ocena warunków rozwoju dębów na podstawie analizy grzybów pod wrględem składu gatunkowego $i$ udziału grup troficznych, tj. symbiontów mikoryzowych, saprotorfow i pasożytôw.

Powierzchnic zalożone w Mstowic, oznaczone jako I i II, a w oryginale projektu $\mathrm{P}_{5}$ i $\mathrm{P}_{6}$ (po $1000 \mathrm{~m}^{2}$ kajda 2 podziajem na 10 podpowierzchni) należa do grupy 16 powiorzchni wytypowanych w Polsce 1 obejmujących reprezentatywne ekosystemy $z$ udziałem dębów.

Powierzchnic w Mstowie odznaczaja sį̨ tym, ze drzewostan jest jednowickowy i wylącznic dębowy z przewaga ilościowa Quercus robur nad Qu. petraca. Drzowostan pochodzi z nasadzenia cręściowo na micjscu spalonego w czasic I wojny swiatowej lasu komunainego, zwanego "Górami", a czę́sciowo na przylegającej do lasu murawie kserotermicznej dżytkowanej jako pastwisko gminne w części zwanej „Golizna". Pod wpływem zalesienia murawa kserotermiczna o kompozycji gatunków zbliżonej do Adonido-Brachypodietum przeksztalca sị w kierunku cieplolubnej dąbrowy reprezentująccj Quercelalia pubescentís.

Wytypowane powierzchnie różaį się ekspozycjq terenu, zwarciem podszycia $i$ intensywnoscia wydepcywania gleby. Powierzchnia I potożona jest na stoku o nachyleniu ok. $30 \%$, o gestym podszyciu z przewaga Prunus spinosa oraz zascznym udziale Rosa canina i Crataegus monogyna nie jest przyjazna dla spacerowiczow, dlatego w nieznacznym stopniu naraziona jest na wydeptywanie.

Powierzchnia II usytuowana na terenie o nachyleniu ok, $5 \%$ i słabo wyksztakconym podszyciu w postaci pojedynczych okazów Juniperus communis i kęp zarośli Pranus spinnsa jest terenem intensywnic wydeptanym.

W ciągu trzech sezonow wegetacyjnych dokonano tącznie 24 obserwacji, w czasie których zbierano na powierzchniach wszystkie pojawiające się gatunki grzybów i liczono ich owocniki, oddzielnie na każdej podpowierzchni. Uzyskene dane co do obfitości owocowania grzybów oraz frekwencji czasowej i przestrzennej zestawiono w tabele analityczne (tab. 4 i 5) oraz syatetyczne (tab. 7 i 8). Na dwóch powierzchniach (w sumie $2000 \mathrm{~m}^{2}$ ) zebrano łącrnie 190 gatunków grzybów makroskopowych. Liczba roślia aaczyniowych na tych powierzchniach wyzosi 87 . Zcbrane grzyby wykazują szerokie zröżnicowanie taksonomiczne i ekologiezne; 9 gatunków należy do Ascomycota a 181 do Basidiomycoia. Reprezentują téz różne grupy troficzne: 80 (czyli $42 \%$ ) tworzy zwiazki mikoryzowe $z$ dębami zas 110 to gatunki saprotorficene rozwijające się na glebie, w warstwie ściólki i na martwym drewnie. Tych ostatnich jest najwięccj: 56 gatunków czyli $51 \%$ grzybów saprotroficzaych zebranych na badanych powierzchniach. Nie stwierdzono pasożytów o owocnikach makroskopowych. $\mathrm{Na}$ uwage zasługuje duża liczba grzybów mikoryzowych, najwyższa spostród 16 badanych powierachni w Polsoc.

$\mathrm{Na}$ podstawie stopnia obfitości i frekwencji wytypowano gatunki dominujące $w$ badanej monokulturze dębowej, a także stwierdzono występowanie gatunków rzadkich oraz zagrożonych, z których 16 wykazanych jest na Czerwoncj Liście gatunków zagtożonych w Polsce. Tomentella lateritia jest gatunkiem nowym dia Polski. 